Natalia Andrienko, Postgraduate Student, Department Processes and Apparatuses of Chemical and Pharmaceutical Industries, National University of Pharmacy, Pushkinska str., 53, Kharkiv, Ukraine, 61002

E-mail: paft@nuph.edu.ua

Rita Sahaidak-Nikitiuk, Doctor of Pharmaceutical Sciences, Head of Department,Department of Processes and Apparatuses of Chemical and Pharmaceutical Industries, National University of Pharmacy, Pushkinska str., 53, Kharkiv, Ukraine, 61002

E-mail: sagaidak_rita@ukr.net

Natalia Demchenko, PhD, Associate Professor, Department of Management and Administration, National University of Pharmacy, Pushkinska str., 53, Kharkiv, Ukraine, 61002

E-mail: demchenata@ukr.net

Natalia Alekhina, PhD, Associate Professor, Department of Pedagogy and Psychology, National University of Pharmacy, Pushkinska str., 53, Kharkiv, Ukraine, 61002

E-mail: alexinanata76@gmail.com

УДК 615.32+582.929.

DOI: 10.15587/2519-4852.2019.178320

\title{
FATTY ACID COMPOSITION OF COMMON BUGLE HERB (AJUGA REPTANS L.)
}

\section{A. Grytsyk, S. Maliuvanchuk}

Мета. Ідентифікаџія та визначення якісного складу та кількісного вмісту жирних кислот у траві горлянки повзучої.

Методи дослідження. Дослідження жирних кислот горлянки повзучої проводили методом газової хромато-мас- спектрометрії, який заснований на утворенні метилових естерів жирних кислот з наступним їх визначенням.

Результати дослідження. Методом хромато-мас-спектрометрії вперше проведено вивчення жирнокислотного складу трави горлянки повзучої (Ajugareptans L.). В результаті дослідження в траві горлянки повзучої було виявлено 22 речовини, з них ідентифіковано - 9 жирних кислот. За кількісним вмістом переважали поліненасичені - ліноленова та лінолева жирні кислоти та насичені - пальмітинова. Їх загальний вміст в перерахунку на суму жирних кислот складав 56,71\% (ненасичені), 28,18\%- насичена. В незначній кількості виявлені - стеаринова, ейкозанова, тетракозанова, бегенова кислоти (6,65\%).

Висновки. Жирні кислоти є важливими біосполуками, які беруть участь у складних метаболічних шляхах, є істотними компонентами ліпідів і клітинних мембран у вигляді фосфоліпідів, тим самим мають велику біологічну роль.

В траві горлянки повзучої в значній кількості містилися ненасичені жирні кислоти, вміст суми яких дорівнював 4706,78 мг/ка, щз майже в 1,4 рази вище вмісту суми насичених жирних кислот (3380,83 мг/к2). Результати досліджень можуть бути використані при розробиі методів контролю якості на сировину горлянки повзучої та одержанні біологічноактивних субстанцій з досліджуваної сировини

Ключові слова: горлянка повзуча, газова хромато-мас-спетрометрія,, жирні кислоти, насичені кислоти,ненасичені кислоти

Copyright (C) 2019, A. Grytsyk, S. Maliuvanchuk. This is an open access article under the CC BY license (http://creativecommons.org/licenses/by/4.0).

\section{Introduction}

Ajuga reptans - perennial plant from the Lamiaceae family. The natural area of the bugle growth is quite widespread: throughout Europe, in the Mediterranean, Asia Minor, Central Asia, China, the Balkan Peninsula, as well as in Afghanistan and Iran, it is also found in North America. It grows in meadows and shrubs, in forest glade and forest edges $[1,2]$.
Many plants of Ajuga genus are used in traditional medicine as a remedy for fever, toothache, dysentery, malaria, high blood pressure, diabetes, gastrointestinal disorders as anthelminthic, diuretic and antifungal, antiinflammatory and anti-mycobacterial agents [3].Some of them also used as insect growth inhibitors. A large number of compounds have been isolated from plants of this genus, including phytoecdysteroids, diterpenoids, triter- 
penes, sterols, anthocyanidin glucosides and iridoid glycosides, flavonoids, triglycerides and essential oils [4, 5].

Common bugle has not been used in official medicine. In the State Register of Medicines of Russia as an antitumor agent and an integral part of the mixture according to M. M. Zdrenko reported another species Ajuga Laxmannii [6, 7]. Scientists also investigated the antiprotozoal effect of herbs extracts of this plant and its use in the treatment of malaria [8].

According to literary sources, N. Sahakyan et al (2010) studied the composition of fatty acids in other species of the Ajuga genus, namely, blue bugle (Ajuga genevensis) and Eastern bugle (Ajuga orientalis). These studies were conducted on samples of intact and callus plants. Six compounds were identified, including palmitic, stearic, oleic, linoleic, linolenic and arachidic fatty acids. The content of unsaturated fatty acids in callus plants grown in the autumn are predominant [9].

According to literary scientific sources, the use of common bugle in folk medicine is known. The bugle is used as an antiseptic, astringent, diaphoretic, wound healing, diuretic and antispasmodic agent, the plant improves metabolism, has a haemostatic effect [10]. The components of the plant help patients with various diseases: rheumatism, diseases of the gastrointestinal tract, diarrhea, pulmonary tuberculosis, inflammation of the appendages, cholelithiasis [11]. Effective use of the common bugle in case of inflammatory diseases of the oral cavity. The common bugle is known to contain volatile oil, tannins and traces of alkaloids. The chemical composition of the plant has been poorly studied, in particular, the fatty acid composition of the herb. It is known that fatty acids are involved in the biosynthesis of fats, metabolisms of hormones, are part of plant cells, have F-vitamin, immunopotentiating and antitumor action, reduce the level of cholesterol in the blood and activate fibrinolysis, regulate the activity of phospholipases, ion channels, information transfer, gene transcription $[12,13]$. According to scientific data, polyunsaturated fatty acids play an important role in the prevention of coronary heart disease, which today came out on top among dangerous human diseases $[14,15]$.

The aim of the study was to conduct research to identify and quantify the content of fatty acids in the herb of the common bugle.

\section{Planning (methodology) of research}

Common bugle - plant used in folk medicine in many countries. The information on the composition of biologically active substances of the common bugle in the literature relates to raw materials growing in the East, Europe or the territory of Russia, at the same time there are no thorough studies of Ukrainian raw materials reserves [16, 17]. As we continue to work on common bugle in Ukraine, we have investigated its fatty acid composition. For the study of fatty acid composition, the method of gas chromatographic mass spectrometry was chosen, which is one of the most suitable methods for the identification of multicomponent mixtures of volatile substances. The method is based on a combination of two separate methods - chromatography and mass spectrometry. The first is to separate the mixture into components, with the second to identify the substance and quantitative analysis [18, 19].

The quantitative content was determined by the internal standards method. The method of the internal standard has advantages, because when used it is not necessary to determine the complete composition of the mixture and the results of the analysis do not depend on the size of the sample [20].

\section{Materials and methods}

The object of study was a Ajuga reptans grass harvested during flowering (April-May) in the natural boundary v. Huta of Bohorodchany district of IvanoFrankivsk region (48.65244 s.1., 24.21541 e.1.)

The fatty acid composition of the common bugle was studied by gas chromatography-mass spectrometry using an Agilent Technologies 6890 gas chromatograph with a 5973 mass spectrometry detector and an HP-5 ms capillary column with an internal diameter of $0.25 \mathrm{~mm}$ and a length of $30 \mathrm{~m}$ by the following method. In a flask of $20 \mathrm{ml}$ was placed a sample of air-dry plant material, was added to the internal standard tridecane at a rate of $50 \mu \mathrm{g}$ per sample, with subsequent calculation of the obtained concentration of the internal standard.

Chromatography conditions: chromatographic column - capillary HP- $5 \mathrm{~ms}$ (with internal diameter $0.25 \mathrm{~mm}$, length $30 \mathrm{~m}$ ), carrier gas velocity (helium) $1.0 \mathrm{ml} / \mathrm{min}$, temperature of the sample injection heater $250{ }^{\circ} \mathrm{C}$, temperature thermostat programmable from 60 to $320{ }^{\circ} \mathrm{C}$ at a speed of $7 \mathrm{deg} / \mathrm{min}$.

To identify the components, the obtained spectra were considered on the basis of the general patterns of fragmentation of organic compounds by electron impact, as well as by comparing the results with the data of the mass spectra libraries NIST05 and WILEY 2007 with the total number of spectra more than 470000 in combination with programs for identification of AMDIS.

Quantitative content (X, mg / kg) was determined by the method of internal standards according to the formula:

$$
X=\frac{P_{1} \times 50}{P_{2} \times m},
$$

where $\mathrm{P}_{1}$ - the peak area of the studied substance;

50 is the mass of the internal standard injected into the sample, $\mu \mathrm{g}$;

$\mathrm{P}_{2}$ - peak area of the standard; $\mathrm{m}$ - sample of raw materials, $\mathrm{g}$.

\section{Results of the research}

He results of the study of fatty acid composition in Ajuga reptans herb are shown in Fig. 1 and Table 1. 


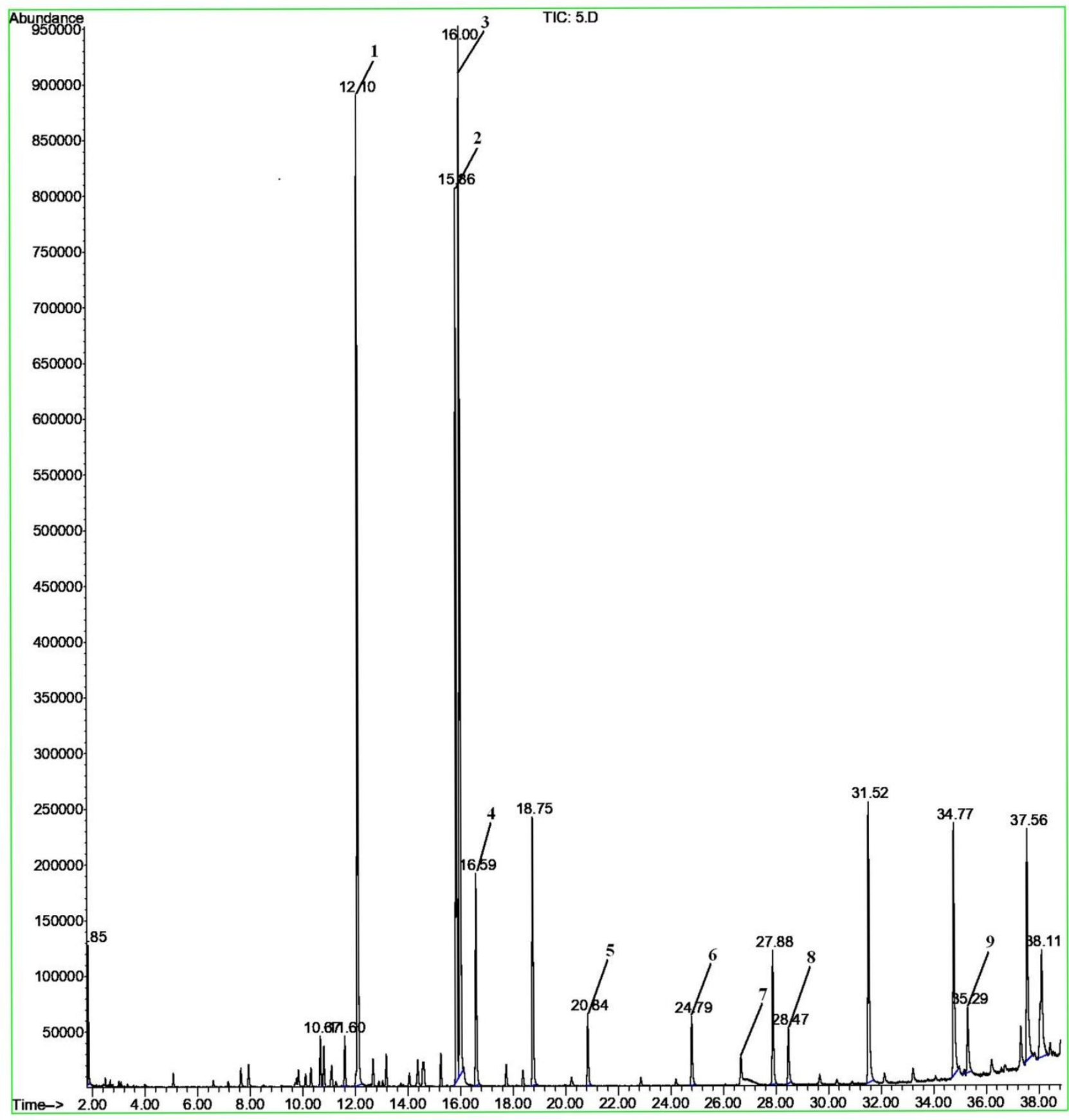

Fig. 1. Fatty acid chromatogram in Ajuga reptans herb:

1 - palmitic; 2 - linoleic; 3-linolenic; 4 - stearic; 5 - peanut;

6 - behenic; 7 - tricosanoic; 8 - lignoceric; 9 - pentacosanoic. 
Qualitative composition and quantitative content of fatty acid composition of the studied Ajuga reptans

\begin{tabular}{|c|c|c|c|c|c|c|}
\hline \multirow{2}{*}{ No. } & \multirow{2}{*}{$\begin{array}{c}\text { The name of the } \\
\text { substance }\end{array}$} & \multirow{2}{*}{$\begin{array}{c}\text { Systematic name } \\
\text { IUPAC }\end{array}$} & \multirow{2}{*}{$\begin{array}{l}\text { Chemical } \\
\text { formula }\end{array}$} & \multirow{2}{*}{$\begin{array}{l}\text { Retention time, } \\
\min \end{array}$} & \multicolumn{2}{|c|}{ Contents } \\
\hline & & & & & $\mathrm{mg} / \mathrm{kg}$ & $\%$ \\
\hline 1 & Palmitic acid & hexadecanoic & $\mathrm{C}_{16} \mathrm{H}_{32} \mathrm{O}_{2}$ & 12.1 & $2338.25 \pm 0.01$ & 21.18 \\
\hline 2 & Linoleic acid & $\begin{array}{c}\text { cis,cis-9,12- } \\
\text { octadecadienoic } \\
\text { acid }\end{array}$ & $\mathrm{C}_{18} \mathrm{H}_{32} \mathrm{O}_{2}$ & 15.84 & $2133.11 \pm 0.04$ & 25.70 \\
\hline 3 & $\alpha$-Linolenic acid & $\begin{array}{c}\text { cis,cis,cis-9,12,15- } \\
\text { octadecatrienoic } \\
\text { acid }\end{array}$ & $\mathrm{C}_{18} \mathrm{H}_{30} \mathrm{O}_{2}$ & 16 & $2573.67 \pm 0.04$ & 31.01 \\
\hline 4 & Stearic acid & octadecanoic & $\mathrm{C}_{18} \mathrm{H}_{36} \mathrm{O}_{2}$ & 16.58 & $526.36 \pm 0.02$ & 6.34 \\
\hline 5 & Arachidic acid & eicosanoic & $\mathrm{C}_{21} \mathrm{H}_{41} \mathrm{O}_{2}$ & 20.84 & $176.08 \pm 0.04$ & 2.12 \\
\hline 6 & Behenic acid & docosanoic & $\mathrm{C}_{22} \mathrm{H}_{44} \mathrm{O}_{2}$ & 24.79 & $185.66 \pm 0.22$ & 2.24 \\
\hline 7 & Tricosanoic acid & tricosanoic & $\mathrm{C}_{23} \mathrm{H}_{46} \mathrm{O}_{2}$ & 26.67 & $=$ & - \\
\hline 8 & Lignoceric acid & tetracosanoic & $\mathrm{C}_{24} \mathrm{H}_{48} \mathrm{O}_{2}$ & 28.47 & $154.48 \pm 0.12$ & 1.86 \\
\hline 9 & $\begin{array}{c}\text { Pentacosanoic } \\
\text { acid }\end{array}$ & pentacosanoic & $\mathrm{C}_{24} \mathrm{H}_{49} \mathrm{O}_{2}$ & 35.29 & $211.36 \pm 0.13$ & 2.55 \\
\hline & $\begin{array}{l}\text { Content of } \\
\text { saturated fatty } \\
\text { acids, \% }\end{array}$ & & & 56.71 & & \\
\hline & $\begin{array}{c}\text { Content of } \\
\text { unsaturated fatty } \\
\text { acids, } \%\end{array}$ & & & 43.29 & & \\
\hline & Total, mg / kg & & & 8298.96 & & \\
\hline
\end{tabular}

The obtained digital material was processed by the method of variational statistics using Student's $t$ test.

\section{Discussion}

About 22 compounds were found in the Ajuga reptans, 9 of which were identified.

Out of the identified compounds, the highest concentration had polyunsaturated $\alpha$-linolenic acid, the content of which was $2573.67 \mathrm{mg} / \mathrm{kg}$ of raw material or $31.01 \%$ of the total content, saturated palmitic acid with a quantitative content of $2338.25 \mathrm{mg} / \mathrm{kg}$ or $21.18 \%$ of the total content.

Also, the unsaturated linoleic acid was dominated by a content of $2133.11 \mathrm{mg} / \mathrm{kg}$ of raw material $(25.70 \%$ of all fatty acids of the bugle). The fatty acid composition was also represented by the glycerides of five fatty acids: stearic, arachidic, behenic, lignoceric, pentacosanoic. Thus, the value of the chemical composition of the raw material of the cervical neck is determined by the significant content of essential fatty acids, which play a number of important biological functions, which act as regulators of exchange processes, in particular, they participate in the lipid metabolism, affect the condition of the vessel wall, counteract the free radical oxidation.
Some of the compounds were not identified due to their lack in the library database.

Limitations of the study. A number of compounds were not identified during the study. The study is limited to the use of raw materials harvested from one site of growth and non-native plants.

Prospects for further research. The results of the study of the fatty acid composition of the aboveground part of the Ajuga reptans indicate the need for a more in-depth study of biologically active substances of this raw material. This raw material can be a promising source of medicines for both internal and external use.

\section{Conclusions}

In Ajuga reptans herb the qualitative and quantitative composition of fatty acids were determined with gas chromatography method.

In the studied raw material, 22 fatty acids were found, 9 of which were identified: among which 2 belong to unsaturated fatty acids, 7 to saturated ones.

In the Ajuga reptans herb, quantitative content was dominated by unsaturated fatty acids: $\alpha$-linolenic acid and linoleic acid, and saturated fatty acids.

\section{References}

1. Ishchuk, L. P. (2018). Verba v etnokulturnykh tradytsiiakh i zvychaiakh ukraintsiv. Etnobotanichni tradytsii v ahronomii, farmatsii ta sadovomu dyzaini. Uman: Sochinskyi M. M., 100-108. 
2. European Pharmacopoeia. Vol. 1-2 (2010). Strassbourg: European Directorate for the Quality of Medicines \& Health Care (EDQM), 3536

3. Willow bark: British Pharmacopoeia. Vol. III (2009). London: Herbal Drugs and Herbal Drug Preparations, 3.

4. Derzhavna Farmakopeia Ukrainy. Vol. 3 (2014). Kharkiv: Derzhavne pidpryiemstvo «Ukrainskyi naukovyi farmakopeinyi tsentr yakosti likarskykh zasobiv», 732 .

5. Boeckler, G. A., Gershenzon, J., Unsicker, S. B. (2011). Phenolic glycosides of the Salicaceae and their role as antiherbivore defenses. Phytochemistry, 72 (13), 1497-1509. doi: http://doi.org/10.1016/j.phytochem.2011.01.038

6. Kishore, N. R., Mangilal, T., Anjaneyulu, N., Abhinayani, G., Sravya, N. (2014). Investigation of anti-inflammatory and in vitro antioxidant activities of hydroalcoholic extract of bark of Salix tetrasperma Roxb. International Journal of Pharmaceutics and Drug Analysis, 2 (5), 506-509.

7. Fuchylo, Ya. D., Sbytna, M. V. (2009). Vepby Ukpainy (biolohiia, ekolohiia, vykorystannia). Kyiv: Lohos, 200.

8. Horelov, O. M.; Kokhn, M. A. (Ed.) (2002). Rodyna Salicaceae Mirbel. Dendroflora Ukrainy. Dykorosli y kultyvovany dereva i kushchi. Pokrytonasynni. Chastyna I. Dovidnyk. Kyiv: Fitosotsiotsentr, 336-379.

9. Ishchuk, L. P. (2015). Rid Salix L. v Ukraini. Visti Biosfernoho zapovidnyka "Askaniia-Nova", 17, 35-43.

10. Nedoseko, O. I. (2014). Borealnye vidy iv podrodov Salix i Vetrix: ontomorfogenez i zhiznennye formy. Nizhnii Novgorod: Izd-vo Nizhegorodskogo gosuniversiteta, 426.

11. Skvortsov, A. K. (1999). Willows of Russia and Adjacent Countries. Taxonomical and Geographical Revision. Joensuu: University of Joensuu, 307.

12. Mola-Yudego, B., González-Olabarria, J. R. (2010). Mapping the expansion and distribution of willow plantations for bioenergy in Sweden: Lessons to be learned about the spread of energy crops. Biomass and Bioenergy, 34 (4), 442-448. doi: http://doi.org/10.1016/j.biombioe.2009.12.008

13. Lakyda, P. I., Heletukha, H. H., Vasylyshyn, R. D. et. al.; Lakyda, P. I. (Ed.) (2011). Enerhetychnyi potentsial biomasy v Ukraini. Kyiv: Vydavnychyi tsentr NUBiP Ukrainy, 28.

14. Lakyda, P. I. (2001). Fitomasa lisiv Ukrainy. Ternopil: Zbruch, 256.

15. Khiteva, O. O. (2010). Sravnitelnoe morfologo-anatomicheskoe izuchenie kory trekh vidov ivy, proizrastaiuschikh na Severnom Kavkaze. Razrabotka, issledovanie i marketing novoi farmacevticheskoi produkcii, 65, 139-142.

16. Derzhavna Farmakopeia Ukrainy. Vol. 1 (2015). Kharkiv: Derzhavne pidpryiemstvo «Ukrainskyi naukovyi farmakopeinyi tsentr yakosti likarskykh zasobiv», 1128

17. Kornilova, O. O., Makarova, O. Ye. (2015). Suchasni problemy standartyzatsii likarskoi roslynnoi syrovyny. Upravlinnia yakistiu v farmatsii. Kharkiv: Vyd-vo NFaU, 64-65.

18. Ternynko, I. I., Kyslychenko, V. S., Khvorost, O. P. (2012). Vyvchennia morfoloho-anatomichnykh oznak pahoniv ta lystia verby bilo. Farmatsevtychnyi chasopys, 2, 42-46.

19. Eremin, V. M., Shkuratova, N. V. (2007). Sravnitelnaia anatomiia kory ivovykh. Brest: BrGU im. A. S. Pushkina, 196.

20. Malychenko, E. V., Lotova, L. I. (1986). Anatomiia kory vidov roda Salix (Salicaceae) srednei polosy evropeiskoi chasti SSSR. Botanicheskii zhurnal, 71 (8), 106-113.

21. Ramos, P. A. B., Moreirinha, C., Santos, S. A. O., Almeida, A., Freire, C. S. R., Silva, A. M. S., Silvestre, A. J. D. (2019). Valorisation of bark lipophilic fractions from three Portuguese Salix species: A systematic study of the chemical composition and inhibitory activity on Escherichia coli. Industrial Crops and Products, 132, $245-252 . \quad$ doi: http://doi.org/10.1016/j.indcrop.2019.02.028

22. Willow bark Salix spp. Analytical, quality control and therapeutic monograph (1999). American Herbal Pharmacopoeia and Therapeutic Compendium. Santa Cruz, 16.

23. Kurkin, V. A., Braslavskii, V. B., Zapesochnaia, G. G. et. al. (2000). Rasteniia semeistva ivovykh - perspektivnii istochnik novykh antimikrobnykh, protivovospalitelnykh i toniziruiuschikh lekarstvennykh sredstv. Poisk, razrabotka i vnedrenie novykh lekarstvennykh sredstv i organizacionnykh form farmacevticheskoi deiatelnosti. Tomsk, 42-43.

24. Islam, S. M., Zahan, R., Nahar, L., Alam, B. M., Naznin, M., Sarkar, G. C. et. al. (2011). Antibacterial, insecticidal and in vivo cytotoxicity activities of Salix tetrasperma. International Journal of Pharmaceutical Sciences and Research, 2 (8), $2103-2108$.

25. Frolova, O. O., Kompanceva, E. V., Dementeva, T. M. (2016). Biologicheski aktivnye veschestva rastenii roda Iva (Salix L.). Pharmacy \& Pharmacology, 4 (2 (15)), 41-59.

26. Brereton, N. J. B., Berthod, N., Lafleur, B., Pedneault, K., Pitre, F. E., Labrecque, M. (2017). Extractable phenolic yield variation in five cultivars of mature short rotation coppice willow from four plantations in Quebec. Industrial Crops and Products, 97, 525-535. doi: http://doi.org/10.1016/j.indcrop.2016.12.049

27. Sulima, P., Krauze-Baranowska, M., Przyborowski, J. A. (2017). Variations in the chemical composition and content of salicylic glycosides in the bark of Salix purpurea from natural locations and their significance for breeding. Fitoterapia, 118, 118125. doi: http://doi.org/10.1016/j.fitote.2017.03.005

28. Borodina, N. V. (2016). Research of volatile compounds from Salix cinerea L. Oxford Review of Education and Science, $1(11), 468-473$.

29. Borodina, N. V., Kovalev, V. N. (2015). Sravnitelnii analiz fenolnykh soedinenii pobegov Salix caprea L., Salix purpurea L., Salix viminalis L. flory Ukrainy. Fenolnye soedineniia: fundamentalnye i prikladnye aspekty. Moscow, 27-33.

30. Borodina, N. V. (2015). Izuchenie letuchikh komponentov Salix caprea L. Proceedings of 4-th European Conference on Biology and Medical Sciences. Vienna, 209-213.

31. Borodina, N. V. (2015). Khromato-mass-spektrometrycheskoe yzuchenye lystev Salix caprea L. Aktualni pytannia rozvytku medychnykh nauk u XXI st. Lviv: Lvivska medychna spilnota, 106-108.

32. Borodina, N., Koshovyi, O., Kovalyov, V. (2016). The chromatography-mass spectrometry study of Salix rosmarinifolia L. Azerbaidzhanskii farmacevticheskii i Farmakoterapevticheskii zhurnal, XVI (2), 15-20.

33. Borodina, N. V., Kovalyov, V. N., Koshovyi, O. N., Stremoukhov, A. A. (2018). The study of Salix myrsinifolia Salisb. leaves by the GC/MS method. The 9th International Conference on Pharmaceutical Sciences and Pharmacy Practice, dedicated to the 100th years anniversary of independent Lithuania's pharmacy. Kaunas: LSMU, 105.

34. Borodina, N. V., Borova, E. B. (2015). Elemental composition of Salix caprea L. Topical issues of new drugs development. Kharkiv: Publishing Office NUPh, 62. 
35. Smart, L. B., Volk, T. A., Lin, J., Kopp, R. F., Phillips, I. S., Cameron, K. D., Abrahamson, L. P. (2005). Genetic improvement of shrub willow (Salix spp.) crops for bioenergy and environmental applications in the United States. Unasylva, 56 (221), $51-55$.

36. Barthlott, W., Mail, M., Bhushan, B., Koch, K. (2017). Plant Surfaces: Structures and Functions for Biomimetic Innovations. Nano-Micro Letters, 9 (2). doi: http://doi.org/10.1007/s40820-016-0125-1

37. Rudall, P. J. (2007). Anatomy of Flowering Plants. New York: Cambridge University Press, 146. doi: http://doi.org/10.1017/cbo9780511801709

38. Lotova, L. I. (2000). Morfologiia i anatomiia vysshikh rastenii. Moscow: Editorial URSS, 528.

39. Evert, R. F. (2006). Esau's Plant Anatomy. New York: Wiley-Interscience, 602. doi: http://doi.org/10.1002/0470047380

40. Dickison, W. C. (2000). Integrative plant anatomy. California: Elsevier, 533. doi: http://doi.org/10.1016/b978-0-12215170-5.x5000-6

41. Barthlott, W., Neithuis, C., Cytler, D., Ditsch, F., Meusel, I., Theisen, I. et. al. (2008). Classification and terminology of plant epicuticular waxes. Botanical Journal of the Linnean Society, 126 (3), 237-260. doi: http://doi.org/10.1006/boj1.1997.0137

42. Barthlott, W., Neinhuis, C., Cutler, D., Ditsch, F., Meusel, I., Theisen, I., Wilhelmi, H. (1998). Classification and terminology of plant epicuticular waxes. Botanical Journal of the Linnean Society, 126 (3), 237-260. doi: http://doi.org/10.1111/j.10958339.1998.tb02529.x

43. Borodina, N. V., Kovalov, V. M. (2018). Mineralnyi sklad deiakykh vydiv rodyny Salicaceae. Zbirnyk naukovykh prats spivrobitnykiv NMAPO im. P. L. Shupyka, 29, 180-187.

44. Kovalov, V. M., Marchyshyn, S. M., Khvorost, O. P. et. al.; Kovalov, V. M., Marchyshyn, S. M. (Eds.) (2014). Praktykum z identyfikatsii likarskoi roslynnoi syrovyny. Ternopil: TDMU, 264.

Received date 05.08.2019

Accepted date 22.08.2019

Published date 31.08.2019

Andriy Grytsyk, Doctor of Pharmaceutical Sciences, Professor, Head of Department, Department of Pharmacy, Ivano-Frankivsk National Medical University, Halytska str., 2, Ivano-Frankivsk, Ukraine, 76018 E-mail: grycyk@ukr.net

Svitlana Maliuvanchuk, Assistant, Department of Pharmacy, Ivano-Frankivsk National Medical University, Halytska str., 2, Ivano-Frankivsk, Ukraine, 76018

E-mail: sv_malyv@ukr.net 